\title{
Fashionable Irony and Stiob: the Use of Soviet Heritage in Russian Fashion Design and Soviet Subcultures
}

\author{
Ekaterina Kalinina
}

\section{Introduction $^{1}$}

Political reformation within the Communist Party of the Soviet Union started in 1985. Widely known as perestroika, it brought a draught of fresh air into the life of Soviet subcultures. Previous bans on musicians' performances and artists' exhibitions were lifted, and many young people who shared the same sense of dissatisfaction and protest towards the dominant ideology and the Soviet life style got an opportunity to express their discontent openly (Kveberg $2012,9)$. And just like that, dress culture became one of the platforms for the mediation of protest and an important indicator of a particular worldview that questioned the dominant communist ideology. Members of subcultures openly mocked the Soviet life style not least in the way how they dressed by combing and mixing together garments and accessories that hardly could be imagined together. Their irony - a 'rhetorical and structural strategy of resistance and opposition' (Hutcheon 1994, 12) - and stiob - a 'ridiculing that tends to veer towards mortifying and even humiliating' (Klebanov 2013, 235) - became the tools to unpack power hierarchies.

After the disintegration of the Soviet Union, when foreign commodities of varying quality flooded the Russian market, many designers built their brand identities on podrazhanie inostrannomu, or 'foreignism', i.e. trying to appear anything but Russian. With time, however, young and aspiring designers felt the need to create a distinct Russian cultural identity and soon enough Russian themes indeed became the entrance card to the global fashion markets something new, something different, something special. What was striking about the most successful of these brands was a humorous attitude to life, to the self and to the symbols of the past. The designers proposed looking at the Russian past and identity ironically, often without searching for a profound

1 This chapter is an edited and updated version of a chapter of my doctoral dissertation: Kalinina, E (2014) Mediated Post-Soviet Nostalgia. Stockholm: Södertörn University.

(C) EKATERINA KALININA, 2019 | DOI:10.1163/9789004366671_010

This is an open access chapter distributed under the terms of the prevailing CC-BY-NC-ND License. 
meaning. They suggested accepting both the past and the present and laughing at some aspects of it.

This humorous twist had another 'fashionable' reincarnation coinciding with Vladimir Putin's third presidential term (2012-2018). Several pro-Kremlin designers and brands such as Antonina Shapovalova and PUTINVERsteher were launched as political projects promoting a mixture of state patriotism and a cult of personal happiness in a disarming ironic manner. However, while the Soviet subcultures used stiob as an effective strategy to mock the Soviet regime, the pro-Kremlin designers promoted official version of patriotism where these modes of joking were used as a strategy to disarm and attract more sympathisers. Against this background, it seems relevant to raise a question about the usage of irony and stiob both in the promotional strategies and in the treatment of national history in Russian dress culture in the 1980s-2010s.

\section{The Rebellious Stiob of the Soviet Subcultures}

The relations between the Soviet system and Soviet subcultures were a complex matter. Even though many subcultures were in opposition to the Communist party, they nevertheless were largely tolerated by the state during late socialism (Steinholt 2005, Zhuk 2010). As Gregory Kveberg (2012) writes, a policy of tolerance allowed official culture and subcultures to evolve together in a dialectical process, with the banning of some cultures in the Soviet Union leading to the emergence of others, creating some sort of hybrid culture, where official and non-official elements were deeply intertwined (Yurchak 2006). This dialectics provided a fruitful arena for the outburst of creativity, which spilled over to the dress culture that in its turn became one of the main instruments adapted by subcultures to mock the Soviet way of life. The underdeveloped Soviet fashion industry with its constant deficit and more often than not poor quality of its products not only bred artisanal dress-makers and seamstresses, but also begot out-of-the-box solutions such as the use of secondhand garments (Bartlett 2010, Gronow \& Zhuravlev 2015, Gurova 2008).

For subcultures, the creative appropriation of second-hand clothes also had an important function - to overturn Soviet the ready-made truths some of these garments or accessories symbolised. Elena Khudyakova, for example, appropriated Soviet military and working uniforms such as vatnik, a warm jacket used in the Tsarist and Soviet armies as well as in the punitive systems. ${ }^{2}$

2 Vatnik (Teplushka) is an element of military ammunition during winter time. Vatnik was made of textile of green colour and had a quilted cotton lining. It was usually put under greatcoat, 
Artistic collaboration between Gosha Ostretsov and Timur Novikov resulted in the collection consisting of costumes of Communist invaders and was dedicated to the resettlement of Communism onto other planets. Ostretsov lucidly ridiculed both the ideals of military might of the Soviet army and the idea of world revolution by adding children's toys and plastic baby night pots to military uniforms.

The type of mockery the members of the subcultures developed is considered to be a specific Soviet phenomenon - stiob, a type of irony, which is defined by its serious attitude to the ideological symbols of the system (Yurchak 1999, 2006). Svetlana Boym $(2001,154)$ wrote that stiob is the ultimate creation of homo sovieticus and post-sovieticus that allows one to domesticate cultural myths'. It 'uses shocking language to avoid a confrontation with shocking issues', as well as tautology, overstatements and trivia (Boym 2001, 154).

Parading the streets dressed in ridiculous looking outfits was a kind of public intellectual epatage, an aggressive and provocative disempowerment of hegemony of the system through using the semiotic resources available within the Soviet discourse of power. But it was not only the communist ideology itself that was being laughed at and mocked, it was also the submissive loyalty and sincere attitudes to this ideology. Through gaudy hyperbole, clowning and semiotic surplus Soviet tackiness, vulgarity and fetishism were overemphasized. By using the same instruments as the state used in order to manifest its power position, the subcultures challenged and sifted power in the society of late socialism.

According to Michel Foucault, resistance to hegemonic discourses is a natural part of how power is exercised (2002). Where there is power, there is always resistance. He writes that resistance to a certain discourse always occurs within it, with the same words and concepts (Foucault 2002). It is not possible to exercise resistance to a discourse without also being a part of it. Resistance is possible when discourses fight for the creation of meaning at strategically organized resistance points, which can break down positions of power in the dominant discourse and force new groupings (Foucault 2002, 106). In practice it meant an automatic reproduction of the form of the sign (a banner or a military uniform, a night pot, a tank-toy), and placement of the sign into a different context (a dress was made out of this red banner or a uniform and a tank toy was placed on a hat). Hence the absurdness of the whole ideological construction, which might not be apparent in the ordinary context, became visible.

however it was allowed to wear it without a coat while at home or during studies (Chernov 2011). 
This ironic treatment of the re-appropriated symbols of Soviet ideology did not always mean a complete degrading of these inherited signs. It also contained a warm and caring attitude towards them. After all they were a part of the everyday life and it was possible for certain affirmative and naive aspects of Soviet culture to preserve their constructive significance. With time progressing critical attitudes towards the Soviet system transformed into explicit cynicism and negative assessment of many spheres of Soviet life. After the fall of the Soviet Union, the Soviet period became discredited, while the identity of an average Soviet person was distorted by the overwhelming presence of the ugly truths of the past. The new Russian political elites demonstratively rejected the Soviet ideas and tried to get rid of the consequences of the 'Soviet experiment' and to bring the country back to the 'normal' condition. At that:

What before had been seen as a symbol of 'national pride', now was viewed as 'collective trauma'. Such reformatting demanded changes in the customary practices: not only the emphasis from the 'heroes' (which seized to be heroes) should have been put on the 'victims', but also the perpetrators should have been punished. Such work demanded great resources and was complemented with great risks. The point was not in the fact that the revealing of the 'real' roles of 'heroes', 'perpetrators' and 'victims' in the society, which went through the civil war, is a painful process; but such abrupt change of the implication of a historical event, functioning as a myth, interferes the whole construction of collective identity. It is not that easy to substitute 'national pride' with 'national trauma' (Malinova 2015).

By mocking Soviet symbols such as Pioneer and military uniforms, the members of subcultures who were still active after the demise of the Union not only removed their heroic pathos, but also re-established sincere and warm attitudes to these symbols, which had often been dismissed during perestroika and during the 1990s.

One of the essential aspects of these dress cultures is a distinct relation to Western consumption. The Soviet state failed to eliminate the appeal of Western goods, which in the society of constant deficit of both necessary and luxury sartorial objects acquired a status of sacred - everyone dreamt of possessing American jeans (Pilkington 1994, Roth-Ey 2011, Rybak, 1990). Fashionistas had good contacts on the black market and were able to lay hands on sartorial import, for which they were accused of creating a cult of Western consumption. But instead of simply mimicking the Western fashions the Soviet subcultures created their own unique dress styles by mixing various elements and styles 
informed by the cultural and social conditions they lived in. They searched for inspiration everywhere - among the stalls of flee-markets, grandmothers' wardrobes, and garbage piles, hence proving that the sartorial appeal was not restricted to the Western looks, but also included Soviet commodities (Petlura 2012, Morozov 2012).

This mode of treating second-hand objects in order to question the normalised social structures by the Soviet subcultures is comparable with the cut 'n' mix, bricolage attitude of Western punk as analysed not least by Dick Hebdige (1979). If one is to follow Hebdige's logic, all subcultures should undertake the same path: starting as styles challenging dominant ideology-(ies), hegemony-(ies) and social normalization(s) through its symbolic forms of resistance, they later become commodified by eventual entrepreneurs to decline later; the Soviet subcultures, or at least some of their practices once subversive, rebellious, and radical, should at some point have become contained and served the mainstream ideology-(ies). It seems that this was to a certain extend the trajectory many Soviet subcultures followed.

The impulsive breakout of subculture fashion started to fade out sometime around 1995, even though the Tishinka flee-market in Moscow, the main threshold of this culture, was still alive (Baster on-line). There were many reasons for this decline. First, around the same time the Western formats of glossy magazines, such as Cosmopolitan and Vogue, introduced Western brands in Russia. Second, subculture designs were not fit for the tough economic rules of the 1990s, let alone to be adopted by large-scale mass production (which was in deep depression by 1998 and still struggling to recover by 2017). Third, when it became possible, some of the designers and artists emigrated to the West and continued their career as professional designers. Meanwhile, some of them left the subculture scene for personal reasons. However, it would be wrong to say that such conceptual artistic practices died for good. Artist Alexander Petlura, for example, continued working with the recycling of second hand clothes and was and still is the most prominent figure in Moscow with his massive collection of historical dress, which he has exhibited in his explorative and provoking performances and installations.

One can say for sure that at least the mocking of Soviet ideals combined with sincere attitudes to it was picked up by designer fashion.

\section{The Commercial Stiob and the Use of the Soviet Heritage}

In the 20oos some the subcultures were absorbed by the growing commercial sector of design, which seized the opportunity and appropriated ironic use of 
the Soviet symbols. Almost simultaneously several designers and artists introduced collections where conceptual art and design were blended in a deliberate provocative way. Designers such as Olga Soldatova (fashion design and jewellery), Katia Bochavar (brand MUCH 2MUCH, jewellery), Denis Simachev (fashion design), Maxim Chernitsov (fashion design) created thought-provoking collections by producing rich and high connotative designs. In 2005, Chernitsov presented his collection Homocosmodromo, in which he explored the theme of space travel using images of Iurii Gagarin and the Soviet space dogs. In his subsequent work he elaborated more on the Russian theme, taking a profound philosophical approach to it (Chernitsov 2012). One example is the Fall - Winter 2010/2011 collection, Russkii Dukh ('Russian spirit'), where the designer investigates in rather poignant form the appearances of Russian spirituality.

Starting from 2003 designer Denis Simachev has presented several collections where he scrutinized the Soviet theme among others. He used the Olympic symbols to signify the period of the 1980s, which framed the happy undertones of the collection - the celebration of youth and light-hearted moments of unlimited daydreaming. Olga Soldatova and Katya Bochavar (who are more artists than strictly speaking fashion designers) created several collections of accessories and jewellery, where they played with such easily recognisable Soviet symbols as the red star, images of Vladimir Lenin, animated films characters, and the symbol of the Soviet industrial pride - airplanes. Compared to Denis Simachev and Maxim Chernitsov they also worked with recycled materials. Katia Bochavar, for example, used pioneer pins, badges with the image of Vladimir Lenin, the red star as well as the old Soviet medals, which she combined with brooches in form of insects (collections: Lenin as a superhero, Russian Phoenix).

What unites these brands is their positioning as shocking and insightful countercultural observers with key objections both to capitalist consumer culture and Soviet ideology - some kind of nihilistic troublemakers that invited smart decoders into the realm of irony and stiob. The descriptions on the designers' websites (such as MUCH2MUCH and Denis Simachev) stated that the brands promoted irony, provocation, intelligence and for Denis Simachev - sex appeal. For example, the name of the brand $\mathrm{MUCH} 2 \mathrm{MUCH}$ already signifies hyperbola and exaggeration. The description in the designer blog states:

MUCH 2MUCH marries two fields: jewelry design and conceptual art, in a deliberate, provocative way. It not only recycles and combines various materials and objects to create each individual piece but, most importantly, it also recycles and combines ideas relative to these materials in 
order to bring about entirely new ones. Each piece tells a story. Each is a part of a larger narrative that is intrinsic to modern life. Many of my pieces weave together stories of different cultures, aesthetics, and lifestyles and, as a result, become metaphors of the modern world itself: a delicate balance of seemingly incompatible notions that nonetheless strive for harmony. I feel that this creates a deeper appreciation of the role of art in maintaining this fragile balance ( $\mathrm{MUCH} 2 \mathrm{MUCH}, \mathrm{blog})$.

The similar could be also said about the fashion brand of Denis Simachev, who uses an inverted logo and both Cyrillic and Latin letters to emphasize the brand's special outlook on life. The description reads: 'the brand looks at things from an extraordinary point of view, doubts common values and brings out hidden facts' (Denis Simachev, official website).

Through the application of the Soviet animated films characters (such as Cheburashka, Volk and Zaiats), the 1980's Olympic mascot, and the Soviet comedy characters, the designer revealed exaggerated sentimentality associated with these Soviet cultural icons both in the past and today. At the same time the constant reproduction of these cultural icons of the Soviet childhood made them almost obsolete - on the one side, their reuse in this new fashion context functions as a stimulus for flashback memories which remind people about positive moments of their lives, on the other hand this repetition risks leaving an empty form, a simulacrum, which is used for a creating a momentary emotional connection between the customer of the brand and the past. The past and especially childhood has become a treasure trove of new business ideas. Being packaged in an attractive way (and it is very difficult to package childhood and Soviet comedy icons in a non-attractive way) and being easily digestible and aesthetically pleasing, it becomes a very successful marketing and advertising tool, especially among young adults. In the culture where childhood and sincerity are the most usable elements for attracting any sort of attention, playing with childhood memories and sentiments is one of the best selling strategies. At the same time, striving for a unique identity, young people are looking back into the past to find styles that suit them and would make them distinguishable in the crowds of the mainstream. Having a t-shirt with your favourite animated film character simultaneously marks a belonging to a specific generation, in this case the last generation of the Soviet children (born approximately between 1980 and 1991), a positive attitude towards one's past, and also self-reflexive ironic attitude.

What is important to keep in mind when it comes to the analysis of these brands and Denis Simachev in particular, is that the recycling of the easily recognisable Soviet symbols (or even objects as in the case with the brand 
MUCH2MUCH) does not signal nostalgia for the Soviet period, in a sense of the longing for the time of the past and willing to restore it. It is a branding strategy and a marketing strategy, which uses positive emotions to sell a product. It does not mean that there is no commercial nostalgia, where the past is being commodified and itself becomes a product one can sell and buy. It is definitely the case, and the designers are also aware of that, as well as they are aware of the nostalgia debates. They consciously deny any political nostalgia for the Soviet past, pointing out that their contribution is in the ironic attitude both to the past and to the present. So, despite of the use of the Soviet past being an important element in Russian fashion in the mid-2000s, it is the attitude with which this past is being used in fashion design that I find the most significant. Denis Simachev says: 'It is widely accepted to knit one's brows and say, 'Yes, it was very difficult, it was a terrible period in the history of our country'. Of course one can moan about it, but one can also smile and fight everything bad that happened with humour' (Simachev 2013). What Denis Simachev sells is an ironic attitude to the past, the present and the future, in other words, it is the ironic stand towards the idea of time, change and age. He says: 'I observe it all from a distance and pick funny moments. I try to transplant all these funny moments onto clothing, or some event or lifestyle, in order to sell it. A person does not buy something Soviet, but he or she buys an emotion' (Simachev 2013).

There is nothing random in the mocking and re-examination of the past by these designers. To include irony does not necessarily mean to exclude seriousness and purpose of this creative production. The description to Katia Bochavar's collection states:

Lenin was our grandfather, a kind, yet austere god. A childhood photograph of my father shows him looking just like the Baby Lenin on the Oktyabrenok badges - the first regalia of a young Communist. This same badge would be pinned on the chest of every seven-year-old during the first days of September. I myself was officially made a Pioneer at the Lenin Museum on Red Square. They placed a red tie around my neck and pinned the badge of a young Leninist closer to the heart, before leading us to the Mausoleum. When I was a teenager, I joined the Komsomol. On this badge, our Vladimir Ilyich was portrayed striding boldly forward, offering himself as an open target for the tide of events rushing by. 'Lenin as a Superhero' is a mocking cry, addressed to our own past: 'Nobody is afraid of you anymore, you Asian tyrant, medieval princeling, dried dummy...' We are the last ones who keep you close to our hearts (Lenin as a superhero, Bochavar, official website). 
Remembering is central to the linking of the past with the lived: through personal memories about Vladimir Lenin, the designer enters collective childhood memories of the whole generation of Soviet children pointing out that they are 'the last ones' who have direct memories of this figure and the Soviet period as a whole. The description of the collection thus combines a sincere memory about one's past and a mocking attitude to it, which liberates from the tyranny of Soviet ideological hegemony.

The Soviet past is present in the memories of the designers and has a material form not only in the objects they operate with (pins with Lenin's head), but also in the modern urban palimpsest. One cannot avoid a direct confrontation with the layers of history, which is present in the everyday life - architecture, interior design and in people's apartment's, and even in people's behaviors and attitudes. Art director of the Denis Simachev brand Ivan Makarov suggests that material markers (monuments, buildings, interiors etc.) and emotional structures (behavioural and emotional characteristics of homo sovieticus) are present on many different levels in contemporary Russian society and that it was impossible to overlook them while working on the collections because fashion, as he believes, is a mirror of whatever happens in society (Makarov 2013). One did not have to be nostalgic for the Soviet times since the Soviet 'aura' has never disappeared from the fabric of day-to-day life (on palimpsest see Oushakine 2009). Hence the designers are not interested in copying or reviving this past. They want to come in contact with the positive aspects of the immediate past and present and then put them in question.

The designs are not depthless. It is not a trivial kitsch as some might think. According to Thomas Kulka (1996), for a cultural form to be certified as kitsch: the subject matter in question has to be emotionally charged; it has to be immediately identifiable; and it should reinforce our basic belief and sentiments, rather than subject them for critical examination. A closer look at the garments of these designers suggests that kitsch is appropriated in order to mock. One of the best examples is the portraits of Vladimir Putin in the flowery frame or Roman Abramovitch on the t-shirts (Denis Simachev brand). Hence these kitschy mocking designs produce a doubt about the brands' belief in their own apparent messages. In these cases, its application diverges from Kulka's definition as it destabilizes the prospect of flawlessness by insinuating its concealed motives. These brands hint at something lying underneath the kitschy recycling of Soviet symbols and icons - they open up rather than close down enquiry. What they bring up for discussion is an inherent presence of the Soviet in the culture and identity of modern Russia - the fact that Vladimir Putin appeared on the t-shirt is not random, but it rather points out to the emergence of a new cult of personality. 
Another aspect where this analysis goes against Kulka's model, is when it comes to the working together of kitsch and irony. Kulka writes that 'one of the salient features of kitsch is that it is always univocal, unambiguous, and deadly serious. It is this seriousness that makes kitsch so pathetic. And it is often its pathos that makes kitsch ridiculous ... irony is incompatible with kitsch' (Kulka 1996, 111). In these cases we see the opposite - kitsch and irony come together. It becomes especially visible in the designs of Katia Bochavar and Denis Simachev who, I would say, produce kitschified parodies of kitsch, some sort of parody of kitsch in a kitschy manner, where kitsch is the serious attitude to the Soviet ideology, Soviet kitsch and consumer culture all together.

The designers' use of the Soviet past cannot be reduced to 'aesthetic cannibalization' (Jameson 1991). Of course, it cannot offer what Frederic Jameson (1991) calls 'genuine historicity' - 'social, historical and existential present and the past as 'referent" as 'ultimate objects'. But the designers' deliberate refusal to do so cannot be read as naïve. What they do in reality is to question the very possibility of any system, including the communist and the capitalist one, any ideology and any 'totalizing' history. These designs are doubly ironic (there is a double coding) - they are ironic both of the Soviet past and the capitalist present. They are ironic towards the system and the aesthetics of Soviet kitsch, but they are also ironic about the capitalist market logic, that everything can be bought and sold. Moreover, they also take an ironic stand towards themselves as being a part of the both systems (being born and raised in the Soviet period and now capitalizing on their own past). It is self-reflexive ironic introversion suggested by looking back to the past. It reveals the social implication of this design - the Soviet is still within us and we still take it seriously. We have not learnt to see it clearly by distancing ourselves from it. Drawing on Foucault's theory of power and discourse, one can suggest that in this particular case the designers use instruments of both systems in order to reveal the working of their ideologies. In this process the ironic echoing of the past marks both continuity and change. It uses its historical memory to signal that this kind of self-reflexive discourse is always bound to social discourse. In this case, the stiob of the designers became a mode of self-reflexivity because its incorporation of the past into its very structures points to the ideological context in a more obvious manner than other forms of humor. Stiob allows speaking to a social discourse by being within it, but without being totally recuperated by it.

One could also argue that this ironic attitude towards the Soviet symbols was reached through the application of a semiotic device called 'camp'. Susan Sontag suggests that 'the essence of camp is the unnatural: of artifice and exaggeration' (Sontag 1964, 53). Camp 'inserts the signifier into quotation marks, theatricalizing it at the expense of the signified' (Christian 2001, 118). What is 
most significant about camp is that it is also double-coded both as a clever protest against nostalgia for the Soviet past and as a reinforcement of nostalgia for the Soviet - simultaneously subversive and reactionary. Camp does not so much 'subvert' or displace the dominant code as it juxtaposes the latter with the 'perverse' code, rendering the sign available to a doubled interpretation [\&] it converts the sign into a lure. Camp creates an oscillation between discursive codes (Christian 2001, 137). Hence, camp can also be applied as an analytical category, because it allows for double-talk and ironic attitude to the subject of inquiry.

Denis Simachev claimed exclusivity in introducing an ironic attitude towards the Soviet past: 'In regard to the references to the UssR, I should say that no one ever played with this type of humour. No one ever looked at it with such stiob' (Simachev 2013). As I have pointed out in the previous section, however, stiob had been used by the members of subcultures as a strategy in their disempowering of the Soviet system, so that the designer was actually following a trail that had already been blazed. Let alone he and the other designers active in this period were not the only ones who took an ironic stand towards the past. However, those who followed them on this creative trail had used irony in a different manner.

\section{Stiob 'Kremlin Style' and the Political Uses of the Past}

During Vladimir Putin presidency, fashion became a platform for visual propaganda. Kremlin-friendly fashion brands such as Antonina Shapovalova and PUTINVERSTEHER promoted state ideology by producing designs for the loyal youth movements.

As a response to the Ukrainian Orange revolution of 2004 Obscherossiyskaya obschestvennaya organizatsiya sodeystviya razvitiyu suverennoy demokratii (ooo SRSD) molodezhnoe dvizhenie Nashi (All-of-Russia Civil Organization for the Promotion and Development of Sovereign Democracy Youth Movement Nashi) was officially launched by the politicians Boris and Vasilii Yakimenko in 2005 (Shevchuk, Kamishev 2005). Nashi claimed to be an anti-fascist organization (subsuming communists and liberals under the term 'fascists') supporting President Vladimir Putin in his battle against the oligarchs (Rosbalt 2005). After a number of scandals where the commissars of Nashi were involved, it became evident that the project had to be rebranded or closed down. In 2012 its leader Vasilii Yakimenko declared that the history of the movement in its existing form had ended, and a new political party would be founded to succeed it. In 2013 it was decided to develop smaller projects with clear objectives aimed 
at promoting patriotism under the umbrella organization Vserossiiskoe Soobshchestvo Molodezhi ('All-Russian Youth Association') (Atwal 2009, 2012).

After the Moscow streets protests caused by election fraud during the parliamentary elections in 2011 it became clear to the advocates of Kremlin's political line that youth politics should be reorganized and the means of persuasion of young people should be changed, as the street politics applied by Nashi youth movement were no longer effective. At the same time, the criminal prosecution of the activists after the Bolotnaia Square demonstration on the 6th of May 2012 in Moscow had a cooling down effect on the mass protest movement in Russia. As a result the state has created another youth organisation - Set' (Network), which started to promote Russian cultural values as defined by the state and its ideologists. Set' became a response to the fastly spreading ideas of liberal democracy and its ideas of civic engagement in Russia by providing an alternative formed around neoconservative ideas, orthodoxy, and support for the president. Instead of focusing on the mobilization of loyal crowds for demonstrations and street protests, the Kremlin turned towards cultural and patriotic upbringing of young people. This is how one of the members of the new movement Set' explains the need of reformation of the youth politics in Russia: 'We have understood that there is nothing to be done on the streets as we have won there, but there should be something new done in youth politics' (quoted in Tumanov and Surnacheva 2014).

Both Nashi and Set' have their own in-house designers, some kind of promoters of the ideologies the organisations advance. Antonina Shapovalova, one of the leaders of pro-Kremlin youth movement Nashi, became the very first designer to promote patriotic glamour, which in 2015 reached its zenith (Feldman 2015a). Shapovalova provided visual support of several campaigns calling for action to join the army and increase birth rates. ${ }^{3}$ The strength of this fashion propaganda was indeed in the medium used to disseminate political messages: fashion often seems to be a non-threatening field and hence functions well to disarm and take people off-guard.

In 2010 Antonina Shapovalova made a collection which was inspired by a military theme - the Collection Fall/Winter 2010-2011, or otherwise called Pobeda \# 22. The collection consisted of men's and women's wear - dresses, bodices and skirts, trousers and jackets adorned with chains, metal studs and rivets, sequins, rough edges, geometric shapes and blackened gold. Erotic glamorization was emphasized with the means of blood-color make-up that covered the naked legs of the female models. The collection also included

3 For more about campaigns promoting nativity see the chapter by Rakhimova-Sommers in this volume. 
t-shirts with various 'patriotic' prints, which is some sort of a trademark of the Shapovalova brand. They were decorated with the number 65 (pointing out to the 65th anniversary of the Great Victory), as well as with aphoristic phrases calling for contributions to the demographic picture of the country with the slogans: 'Mating is pleasant and helpful!' Razmnozhat'sia priiatno i polezno! and mocking those who ditch military service.

Shapovalova's designs called for patriotic devotion to Russia in the form of personal involvement in supporting the state's decisions and actions, which she calls 'an active civic position' (Shapovalova 2013). By amalgamating patriotic action with creative practice she defined the role of cultural industries in the politics of the state as supportive and propagandistic. By looking for inspiration for her collections in the past, she also introduced a specific take on history, which is deprived both of the negative reminiscences and direct memories of the Soviet past. She operates with what Marianne Hirsh (2008) calls post-memories, i.e. the second and third generation's memories about historical events that they have never experienced personally but rather through media and popular culture. Shapovalova's perception of the Soviet past is influenced by the mainstream media and political discourses, especially the discourses on WwII and the indisputable heroic role of the Red Army in the liberation of Europe. Hence it comes with little surprise that the visual language of Shapovalova's patriotism aimed at strengthening and directing the passions of young people towards personal sacrifices for the state and the country.

I would argue that Shapovalova's use both of history as an inspirational material and of irony and stiob as tools for unpacking the past and present and constructing Russian identity is the opposite of what the members of the subcultures did in the 1980s. Instead of questioning military power and stagnant power hierarchies, she glorifies the country's military might and reinforces $\mathrm{Pu}$ tin's 'power vertical' through her fashion design. In Shapovalova's collection, she turns to the main uniting event - the Great Patriotic War and the Victory Day, hence intensifying the cult of the war and its centralizing role in the reconstruction of national identity in Russia. While doing so she redirects attention towards the sincerity of sacrifice in a military battle and its heroic nature. She says:

It so happens that lately we perceive the celebration of Victory too formally. For 65 years, an emotional message became weak and is broadcasted more out of inertia, and not from the heart. In this collection, I want to focus on the personal attitude to victory, think about the place of heroism in the context of the everyday. (Shapovalova, official website) 
Shapovalova frequently invokes sincerity as an important value which Russians have lost, but should have among their principal virtues. By excavating memories of the Great Patriotic War, Shapovalova indirectly looks back on and romanticises Soviet times by searching for sincerity there. This sincerity had two related but distinct meanings: as a way to explore life in the past (in this case, the Soviet past), and as an intrinsic characteristic of that life itself: 'In both these senses, sincerity is further related to a set of other terms: idealism, romanticism, humanism, purity, friendship, comradeship, self-sacrifice, etc.' (Yurchak 2008, 257). Shapovalova claims sincerity towards the past, while in fact she is one of those who contributes to the Kremlin's discursive and ritualistic officialdom.

However, it is difficult to catch her on being insincere - any critic and accusations of being a political project the designer fights back by presenting her brand as stiob. She called it a 'provocation with a smile', and disarmed anyone who tried to make her responsible for promoting official propaganda, even though it is clear that Antonina Shapovalova acted as a mouthpiece for many of Nashi's projects. While the subculture used stiob as an effective strategy to mock the Soviet regime, in a pro-state movement that promotes the official, patriotic line, stiob becomes a powerful tool for disempowerment of the propaganda's target audiences. The designer not only admits that her designs are propagandistic, but overidentifies with the propaganda and ridicules it. By making the viewer believe that her work is just a harmless joke, the designer induces the viewer or consumer to let his or her guard down and assume that it is not propaganda. Shapovalova's second step is to claim that her collections are 'provocative' and to overidentify with provocative action. The word 'provocative' is usually understood as a negative attribute, indicating an action committed to cause a strong reaction by creating a difficult situation or consequences for the one being provoked. However, in this case provocation is seen as a positive act directed towards mobilizing young people to be more active in the life of the country. However, this mobilization is supposed to be ideologically 'correct' - activities should fall within the ideological guidelines laid out by the youth movement and the ruling party. By claiming that her designs are provocative, the designer safeguards herself from criticism by announcing that everything she says and does is only a joke, although with a grain of truth in it: 'Every print is a joke, and, as we know, there is a part of truth in every joke!' (Shapovalova 2013).

Patriotic fashion has not stopped with Shapovalova but intensified with the annexation of Crimea. The year 2014 was rich on patriotic creativity in Russia advancing 'patriotic fashion'. Patriotic frenzy, which overwhelmed Russian society in connection with the Crimean annexation and the feeling of empathy 
for people living in Donbas region in Eastern Ukraine, further materialized in dress culture. Internet shops offered a variety of t-shirts with encouraging prints such as 'Russia,', 'I am Russian', 'Crimea is ours', 'Polite people' etc. The youth organisation Set' staged an 'ironic clothes exchange campaigns' in several cities in Russia. People could get 'patriotic' t-shirts in exchange for clothes of 'foreign' fashion brands. Designers working for and together with Set' mediated political messages through cultural and artistic practices. Set's launched several initiatives such as competitions for the best design to stimulate young artists and fashion designers to produce patriotic designs that would boost moral spirit and reflect Russian identity. Young Ukrainian Anna Kreydenko even became the own in-house designer of Set' and soon after debuting with her first collection already showcased it at the fashion show Novyi Russkii ('The New Russian') organized by Set' in Sevastopol, Crimea, in May 2014.

Kreydenko is part of the designer collective PUTINVERSTEHER, which provides another exiting example of appropriation of stiob. The name of the brand is itself an ironic appropriation of the German term Putin-versteher, the 'prominent German Putin-Empathizers (from Versteher or, literally 'understander' in German)' who 'serve as Putin's first line of defense against European sanctions for the Anschluss of Crimea' (Gregory 2014). The brand overidentifies with those who support Russia and Putin's politics, turns the negative connotation of the word around and makes it its strength by pointing out to the 'patriotic' aspect of it. The slogan says: 'By wearing the clothes by PUTINVERSTEHER you not only support Putin, you challenge the whole world with its corporations, revolutions, humanitarian bombing, double standards and beardy women' (official Facebook page <https://www.facebook.com/Putinversteher-92325493 $7704512 />)$. While the description of the brand refers to such sensitive issues as gay marriage and non-governmental organizations, the imagery of the brand consists of military symbols combined with romantic outfits, which visually support the movement's manifesto which proclaims its role in defending 'traditional family values', Russian culture and history, the legacy of the Great Patriotic War, and support for the president of the Russian Federation.

This type of irony is allowed and approved within the frames of the Kremlin's political discourse. Shapovalova's case, together with Katya Dobryakova and Alexander Konasov, AnyaVanya and PUTINVESTEHER makes a viewer believe that 'freedom of artistic expression' is allowed in Russia. They play the role of 'agent provocateur' by openly mocking even the president of the country. Antonina Shapovalova's underwear with slogans like 'PUTin the Best' or Volodia, ia s Toboi (Volodia, I am with you) as well as t-shirts and sweaters of PUtinVersteher with images of Putin and other prominent Russian politicians are in reality a mockery of those who believe in the possibility of criti- 
cism directed towards the political elites of Russia. In fact, mockery and criticism are possible only if they are allowed and sponsored by the state itself.

Even their revoking of the military thematic and the use of war imagery rests within the boundaries of the limited criticism. It promotes heroic pathos, not calls for reflection on war atrocities or criticism towards the actions of the Red Army in Europe. The duality of these designs is also well illustrated through the combination of the evening and cocktail garments with propaganda tshirts with catchy slogans, which mock European democracy and values, European sanctions against Russian politicians and even Turkey. ${ }^{4}$ It promises the masses access to wealth and power of elites through sacrifice and devotion, and the theme of war serves this purpose well. Certainly, warfare cannot be attractive, so the designers turn war into a game and a glamourous event, where blood becomes an accessory and tragedy of the war is in the past. The imagery of the catwalks, with fleeting dresses in the women's line, creates a myth of a distant past and projects it into an alternative present or future where wars are, or will be, victorious and death impossible. ${ }^{5}$ Their designs focus dramatically not only on the tantalising promises of a utopian future, but more importantly on the utopian version of the past and present.

Just like many artists and designers opened up in the past to revolutionary ideas and propaganda, this new generation of designers responded to the call to work towards the country's restoration after 'the greatest geopolitical catastrophe of the 2oth century' and the supposed anarchy of the 199os.

\section{Concluding Remarks}

The fashion brands presented in the last section of this chapter illustrate a new turn in Russian fashion culture and the Kremlin's youth politics: fashion becomes an active propaganda tool that mediates the state politics and ideology. The Kremlin designers show their collections during the official festivities and have exclusive entrance to the most visited cultural platforms. This is a new type of fashion, which is orientated to ideologically indoctrinate masses with

4 On November 24, 2015 a Russian military plane was taken down by Turkish military forces. This incident caused a diplomatic crisis between Russia and Turkey and resulted in viral antiTurkish campaign in Russia. Several 'patriotic designers' such as Alexander Konosov (famous for his patriotic prints, such as 'They are patriots, and you?') and Katya Bodryakova announced a production of 'patriotic' t-shirts to support Russia's sanctions towards Turkey. See more at: <http://rusnovosti.ru/posts/399148>, accessed February 21, 2018.

5 For more examples of the futuristic imagery and its function in the Russian contemporary culture see the chapter by Majsova in this volume. 
the means of visual propaganda. At the same time, the Kremlin harvests 'ideologically correct' commercial fashion brands and benefits from their 'right' patriotism, which is promoted through 'post-popular' (Konosov), non-banal (Dobriakova) ironic designs. The ironic language and immediacy of the imagery of these brands make a direct appeal to an emotional rather than intellectual response. Targeting predominantly young people, these fashion designs intensify myths about World War II and facilitate the mobilisation of the state ideology in which the authority of the present dictates a certain presentation of the past. In contrast to the second-hand clothes found at flea markets stalls (and used by artists such as Alexander Petlura, who believed that these garments breathe history and allow us to become part of history by wearing them, or by reenactment groups whose members believe that wearing the original garments stimulates and enhances the experience of the events by materialising them), modern design creates not a connection with history, but the illusion of such a connection. As new fashion products, which do not transmiss a conscious memory of former users and has none of the strangeness of old clothes, which unavoidably exists in the case of vintage dress and deepens the gap between the past and the present, these designs have the potential to appeal to mainstream customers. The strangeness of the past also is minimised by the removal of all negative memories, while only positive emotions are sold for consumption. In their toolboxes irony and stiob become instruments for the re-establishment of state hegemony through disempowerment and confusion of the consumer. At the same time they have another alluring duality: they simultaneously lay claim to historicity and deny that they do so by hiding behind a notion of fashion as something superficial. In this way fashion becomes a perfect weapon of manipulation: it disarms its viewer and then mediates its message still more effectively than any pamphlet or speech would have done.

\section{References}

Atwal Maya et al. 2012. "The Youth movement Nashi: contentious politics, civil society and party politics." East European Politics 28, no. 3, 256-266.

Atwal Maya. 2009. "Evaluating Nashi's Sustainability: Autonomy, Agency and Activism." Europe-Asia Studies 61, no. 5, 743-758.

Bartlett, Djurdjia. 2010. FashionEast: The Spectre that Haunted Socialism. Cambridge, Mass. MIT Press.

Boym, Svetlana. 2001. The Future of Nostalgia. New York: Basic books.

Buster, Misha, Irina Meglinskaia. 2011. Alternative Fashion before Glossies: 1985-1995. Moskva: August Borg. 
Chenitsov, Maksim. 2007. "MAX CHERnitsov SPRING-SUMMER 2005 «HOMOCOSMоDromo»" Video, 9:27. Accessed February 21, 2018. <https://www.youtube.com/ watch?v=FdbMDkC3mpk $>$.

Chernov L.A. 2011. "Uniforma ofitserov russkoi armii v Man'chzhurii v gody russkoiaponskoi voini 1904-1905." Vestnik Ivanovskogo Gosudarstvennogo Universiteta. 62-68.

Christian, Laura. 2001. "The signs send-up: Camp and the performing subject of Semiosis." Semiotica 137 (1/4): 117-138.

Denis Simachev: <http://www.denissimachev.com/>. Link is no longer working.

Fel'dman, Ievgeniia. 2015. "Vse Idiot po Planu." Moskovski Militari Glamour. Foto Istoria.

Fel'dman, Ievgeniia. 2015. Novaia Gazeta, July 12, 2015. Accessed February 21, 2018. <http://www.novayagazeta.ru/photos/69150.html>.

Foucault, Michel. 2002. Archeology of knowledge. Psychology Press.

Gregory, Paul Roderik. 2014. "Empathizing With The Devil: How Germany's PutinVerstehers Shield Russia." Forbes, April 5, 2014. Accessed February 21, 2018. < http:// www.forbes.com/sites/paulroderickgregory/2014/04/05/empathizing-with-thedevil-how-germanys-putin-verstehers-shield-russia/>.

Gronow, Jukka; Sergey Jhuravlev. 2015. Fashion meets socialism. Vantaa: Suomalaisen Kirjallisuuden Seura.

Gurova, Olga. 2008. Sovetskoe nizhnee belje: Mezhdu ideologiei i povsednevnost'iu. Moskva: Novoe Literaturnoe Obozrenie.

Hebdige, Dick. 1979. Subculture: The Meaning of Style. Taylor and Francis.

Hirsch, Marianne. 2008. "The Generation of Postmemory." Poetics Today 29 no.1: 103-128.

Jameson, Frederic. 1991. Postmodernism, or, The Cultural Logic of Late Capitalism. Verso. Kalinina, Ekaterina. 2014. Mediated Post-Soviet Nostalgia. Stockholm: Erlanders.

Kulka, Thomas. 1996. Kitsch and art. Pennsylvania: Pennsylvania State University Press. Makarov, Ivan. 2013. Interview by the author. Tape recording.

Makarov, Ivan. 2013. Interview by the author. Tape recording. Moscow.

Malinova, Olga. 2015. "Obshchee proshloe: Chto sluchilos' s Rossiei v 1917 godu." RBK, 16 Novermber 16, 2015. Accessed February 21, 2018. <http://www.rbc.ru/opinions/socie ty/o6/11/2015/563c9f2d9a7947892041ff82>.

Morozov, Vladimir. 2012. Interview by the author. Tape recording. Moscow.

MUCH2MUCH. n.d. Accessed February 21, 2018. < https://www.blogger.com/profile/128 $10938028139000765>$.

Nashi movement. n.d. Accessed February 21, 2018. <http://nashi.su/>

Oushakine, Sergey. 2009. The patriotism of despair: Nation, War and Loss in Russia. Ithaca: Cornell University Press.

Petlura, Alexander. 2012. Interview by the author. Tape recording. Moscow. 
Pilkington, Hilary. 1994. Russia's Youth and its Culture: A Nation's Constructors and Constructed. London and New York: Routledge.

Roth-Ey, Kristin. 2011. Moscow Prime Time: How The Soviet Union Built the Media Empire that Lost the Cultural Cold War. Ithaca: Cornell University Press.

Ryback, Timothy. 1990. Rock Around the Bloc: A History of Rock Music in Eastern Europe and the Soviet Union. Oxford and New York: Oxford University Press.

Set's. n.d. Accessed February 21, 2018. <http://проектсеть.pф/>.

Shapovalova, Antonina. 2013. Interview by the author. Tape recording.

Shapovalova. Antonina. n.d. <http://shapovalova.ru/>. Link is no longer working.

Shevchuk, Mikhail and Dmitry Kamyshev. 2005. "Obyknovennyi 'Nashizm," Kommersant. February 21.

Simachev, Denis. 2013. Interview by the author. Tape recording. Stockholm.

Smith, Kathleen. 2002. Mythmaking in the New Russia: Politics and Memory During the Yeltsin Era. Ithaca, NY: Cornell University Press.

Sontag, Susan. 1964. "On camp." Partisan Review 31(4): 515-530.

Steinholt, Yngvar. 2005. Rock in the Reservation. New York and Bergen: Mass Media Music Scholars' Press.

Tumanov Grigoriy and Elizaveta Surnacheva. 2014. "Nashi' 'Seti' pritashchili..." Kommersant. Vlast'. July 7, 2014. Accessed February 21, 2018. <http://www.kommer sant.ru/doc/2499143>.

Volčič, Zela. 2007. 'Yugo-nostalgia: Cultural Memory and Media in the former Yugoslavia', Critical Studies of Media Communication 24, no. 1:21-38.

Yurchak, Alexei. 1999. "Gagarin and the Rave Kids: Transforming Power, Identity, and Aesthetics in the Post_Soviet Night Life." In Consuming Russia: Popular Culture, Sex, and Society Since Gorbachev. ed. Adele Barker, 76-109. Durham, NC: Duke University Press.

Yurchak, Alexei. 2006. Everything Was Forever until It Was No More: The Last Soviet Generation. Princeton, NJ: Princeton University Press.

Yurchak, Alexei. 2008. "Post-Post-Soviet Sincerity: Young Pioneers, Cosmonauts and other Soviet Heroes Born Today." In What is Soviet Now? Ed. Thomas Lahusen and Peter Solomon, 258-276. Berlin/Münster: LIT Verlag.

Zhuk, Sergei. 2010. Rock and Roll in the Rocket City: The West, Identity, and Ideology in Soviet Dniepropetrovsk, 1960-1985. Washington, D.C.: Woodrow Wilson Center Press. 